\title{
A STUDY ON THE RELATIONSHIP OF DEVIATED NASAL SEPTUM WITH MIDDLE EAR PRESSURE AMONG PATIENTS TREATED IN A TERTIARY CARE CENTRE
}

\author{
Rajesh $R^{1}$
}

${ }^{1}$ Assistant Professor, Department of ENT, Government Medical College, Trivandrum.

ABSTRACT
BACKGROUND
It is a matter of controversy that whether deviated nasal septum is contributing to Eustachian tube dysfunction. In this study, the
investigator observed a number of patients with deviated nasal septum (DNS) undergoing surgical correction and was interested
to find out whether DNS was contributing to the development of Eustachian tube dysfunction (ETD) in these patients.
Aims of this study- (i) To find the incidence of decrease in the negativity of middle ear pressure (MEP) in patients undergoing
septoplasty for deviated nasal septum, and (ii) Among patients undergoing septoplasty, to study the relative proportion of
decrease in the negativity of MEP in patients who are also having allergic rhinitis and chronic sinusitis.
Settings \& Design- This was a prospective analytical study done in a tertiary care centre in south India.

\section{MATERIALS AND METHODS}

This study included adult patients with deviated nasal septum who were posted for septoplasty in a particular unit in ENT Department of this institution during a period of six months, and among them, those who are having a negative middle ear pressure in either ear preoperatively were included in this study. For these patients, tympanometry was repeated six weeks after septoplasty and any change in the middle ear pressure was noted.

\section{RESULTS}

The study was done in 61 ears which had negative MEP preoperatively. Six months after septoplasty, a decrease in the negativity of MEP was observed in 27 (44.3\%) ears. In patients who were also having allergic rhinitis and chronic sinusitis, a decrease in the negativity of MEP was observed only in $24.1 \%$ and $29.4 \%$ respectively.

\section{CONCLUSION}

The study showed that DNS may be a factor that contributes to ETD, but correction of DNS alone will not improve Eustachian tu be function, without treating allergic rhinitis or chronic sinusitis in patients having any of these.

\section{KEYWORDS}

Deviated Nasal Septum (DNS), Septoplasty, Eustachian Tube Dysfunction (ETD), Tympanometry, Middle Ear Pressure (MEP).

HOW TO CITE THIS ARTICLE: Rajesh R. A study on the relationship of deviated nasal septum with middle ear pressure among patients treated in a tertiary care centre. J. Evolution Med. Dent. Sci. 2017;6(16):1235-1238, DOI: 10.14260/Jemds/2017/268

\section{BACKGROUND}

In the outpatient department, this investigator observed a number of patients with deviated nasal septum (DNS), and on examination, many of them showed retracted tympanic membrane and conductive hearing loss. He was interested to find out whether DNS was contributing to the development of Eustachian tube dysfunction (ETD) in these patients.

Nasal septum separates the two nasal cavities. Its deviation can produce nasal obstruction, headache, epistaxis, hyposmia, external nasal deformity and can lead to paranasal sinus and middle ear problems. When symptomatic it can be corrected by procedures like septoplasty or submucous resection.

The Eustachian tube is a channel connecting the middle ear cavity with the nasopharynx. Its main functions are ventilation of middle ear to equilibrate middle ear pressure with atmospheric pressure, and drainage and clearance of

Financial or Other, Competing Interest: None.

Submission 17-01-2017, Peer Review 09-02-2017,

Acceptance 16-02-2017, Published 23-02-2017.

Corresponding Author:

Dr. Rajesh $R$,

Assistant Professor, Department of ENT,

Government Medical College, Trivandrum.

E-mail: drrrajeshent@gmail.com

DOI: $10.14260 /$ jemds $/ 2017 / 268$

\section{(c) $(1) \ominus$}

secretions from the middle ear into the nasopharynx. For normal hearing, it is essential that pressure on the two sides of the tympanic membrane should be equal.

When tube is blocked, first oxygen and later carbon dioxide \& nitrogen in the middle ear diffuse into the blood. This results in negative pressure in the middle ear and retraction of tympanic membrane, and later locking of the tube with collection of transudates and later exudates and even haemorrhage. Prolonged tubal block leads to otitis media with effusion, atelectasis, retraction pockets, cholesteatoma and erosion of incudostapedial joint. The common causes for ETD are upper respiratory infections, allergic rhinitis, nasal polyp, deviated nasal septum, hypertrophied adenoids, nasopharyngeal mass, cleft palate, functional, Down's syndrome, etc.

The principle of tympanometry is that when a sound signal of lower frequency like $220 \mathrm{~Hz}$ is introduced into a sealed external canal, it strikes the tympanic membrane, some of which is absorbed and the rest is reflected. More sound energy is reflected when tympanic membrane is stiff and less when it is compliant. The pressure at which maximum compliance occurs is a measure of middle ear pressure (MEP). The ear canal pressure is swept from +200 daPa to -200 daPa and a pure tone is presented to plot out the admittance as a function of external canal pressure. The peak of the curve corresponds to the situation where the pressure 
difference across it is zero. This curve is the tympanogram. ETD can produce negative MEP which can be measured by tympanometry.

Aims of this study were (i) To find the incidence of decrease in the negativity of middle ear pressure (MEP) in patients undergoing septoplasty for deviated nasal septum, and (ii) Among patients undergoing septoplasty, to study the relative proportion of decrease in the negativity of MEP in patients who are also having allergic rhinitis and chronic sinusitis.

\section{Review of Literature}

On review of literature, studies by Duran $\mathrm{K}$ et al, ${ }^{1}$ Salvinelli $\mathrm{F}$ et $\mathrm{al}^{2}$ and Abdel-Naby Awad OG et $\mathrm{al}^{3}$ showed that nasal septoplasty significantly improved Eustachian tube function, thereby normalising the MEP. A study by Chmielik M et al ${ }^{4}$ showed that decreased nasal patency had an impact on the function of the middle ear, and the study by Mehrotra $\mathrm{N}$ et $\mathrm{al}^{5}$ suggested that there was a strong correlation between DNS and middle ear pathology. In a study conducted by Maier W et $\mathrm{al}, 6$ a tendency towards normalisation of tubal parameters was observed 6 to 8 weeks after surgery; while the study by Kamal NP et $\mathrm{al}^{7}$ favoured the observation that surgery for nasal obstruction significantly improved tubal function and middle ear ventilation by 4 weeks postoperatively.

On the contrary, studies by Sahin MI et al, ${ }^{8}$ Eyigör $\mathrm{H}$ et al, ${ }^{9}$ Davari $\mathrm{R}$ et $\mathrm{al}^{10}$ and $\mathrm{Tan} \mathrm{M}$ et $\mathrm{al}^{11}$ showed that septoplasty didn't have considerable effect on Eustachian tube function or MEP; and surgical correction of a nasal septal deviation before ear surgery such as tympanoplasty was not justified.

In the study by Livi $\mathrm{W}$ et al,12 tubal dysfunction was ascertained in $33.3 \%$ of the patients with structural nasal obstruction and in $66.6 \%$ of the patients with functional nasal obstruction. A study by Filipović SA et al ${ }^{13}$ showed that pathological form of tympanograms was more often present in purely inflammatory changes of nasal cavities than in mechanical nasal obstruction like in DNS. Inflammatory conditions like allergic rhinitis and chronic sinusitis lead to ETD and negative MEP. Studies by Karatzanis AD et al ${ }^{14}$ and Rudmik L et $\mathrm{al}^{15}$ showed that mere correction of DNS didn't have much effect on allergic rhinitis and chronic sinusitis respectively, and thereby on Eustachian tube function and MEP.

Since the results of the studies were highly variable, the present study was intended to find out the relationship between nasal septal deviation and Eustachian tube dysfunction among patients in our setup.

\section{MATERIALS \& METHODS}

This was a prospective analytical study done in a tertiary care centre in south India. Approval was got from the institutional ethical committee for research works, and informed consent was taken from the participants.

\section{Inclusion Criteria}

Patients above the age of 18 years with DNS who were posted for septoplasty in a particular unit in the department of ENT of this institution during a period of 6 months.

\section{Exclusion Criteria}

(i) Ears without intact tympanic membrane, and (ii) ears with intact tympanic membrane, but without negative MEP.
One day prior to surgery, in the Audiology section of this institution, tympanometry was done in each ear with intact tympanic membrane, and those who are having a negative MEP in either ear preoperatively were included in the study. Data was collected as per a proforma, which included basic demographic data of the patient, case history, clinical examination and details of the surgery. For these patients, tympanometry was repeated 6 weeks after septoplasty and any change in the MEP was noted. The results were analysed using appropriate statistical methods.

\section{RESULTS}

Among the 242 ears in 121 patients who underwent septoplasty, an intact tympanic membrane was seen in 217 ears, out of which 61 had a negative MEP.

\begin{tabular}{|c|c|c|}
\hline Tympanic Membrane & Number of Ears & $\mathbf{\%}$ \\
\hline Intact & 217 & 89.7 \\
\hline Perforated & 25 & 10.3 \\
\hline Total & 242 & 100 \\
\hline
\end{tabular}

Table 1. Incidence of Intact Tympanic Membrane among Patients Undergoing Septoplasty

\begin{tabular}{|c|c|c|}
\hline $\begin{array}{c}\text { Negative MEP } \\
\text { Preoperatively }\end{array}$ & $\begin{array}{c}\text { Number of } \\
\text { Ears }\end{array}$ & $\mathbf{\%}$ \\
\hline Present & 61 & 28.1 \\
\hline Absent & 156 & 71.9 \\
\hline Total & $\mathbf{2 1 7}$ & $\mathbf{1 0 0}$ \\
\hline
\end{tabular}

Table 2. Incidence of Negative Middle Ear Pressure among ears with intact Tympanic Membrane

Six months after septoplasty, a decrease in the negativity of MEP was observed in 27 ears. Among the ears studied, the average preoperative MEP was $-65.4 \mathrm{daPa}$ which became 42.4 daPa after 6 months. Type $\mathrm{C}$ tympanogram was observed in 23 ears preoperatively, which was reduced in 14 ears postoperatively.

\begin{tabular}{|c|c|c|}
\hline $\begin{array}{c}\text { Negativity of } \\
\text { MEP Postoperatively }\end{array}$ & $\begin{array}{c}\text { Number of } \\
\text { Ears }\end{array}$ & \% \\
\hline Decreased & 27 & 44.3 \\
\hline Not decreased & 34 & 55.7 \\
\hline Total & $\mathbf{6 1}$ & $\mathbf{1 0 0}$ \\
\hline
\end{tabular}

Table 3. Decrease in the Negativity of MEP in Patients who had Negative MEP Preoperatively

There were 17 patients with allergic rhinitis. Improvement in MEP was seen in 7 out of 29 ears among them.

\begin{tabular}{|c|c|c|}
\hline Patients with Allergic Rhinitis & $\begin{array}{c}\text { Number } \\
\text { of } \\
\text { Ears }\end{array}$ & $\%$ \\
\hline $\begin{array}{l}\text { Decrease in Negativity } \\
\text { of MEP Post-Operatively }\end{array}$ & 7 & 24.1 \\
\hline $\begin{array}{l}\text { No Decrease in Negativity } \\
\text { of MEP Post-Operatively }\end{array}$ & 22 & 75.9 \\
\hline Total & 29 & 100 \\
\hline \multicolumn{3}{|c|}{$\begin{array}{l}\text { Table 4. Decrease in the Negativity of } \\
\text { MEP in Patients who had Allergic Rhinitis }\end{array}$} \\
\hline
\end{tabular}




\begin{tabular}{|c|c|c|c|}
\hline & $\begin{array}{c}\text { No. of Ears with } \\
\text { Improvement in } \\
\text { MEP }\end{array}$ & $\begin{array}{c}\text { No. of Ears } \\
\text { with no } \\
\text { Improvement } \\
\text { in MEP }\end{array}$ & Total \\
\hline $\begin{array}{c}\text { Patients } \\
\text { with } \\
\text { Allergic } \\
\text { Rhinitis }\end{array}$ & 7 & 22 & 29 \\
\hline $\begin{array}{c}\text { Patients } \\
\text { without } \\
\text { Allergic } \\
\text { Rhinitis }\end{array}$ & $24.1 \%)$ & $(75.9 \%)$ & $(100 \%)$ \\
\hline \multicolumn{3}{|c|}{ Table 5. Improvement in MEP in Patients } \\
with \& without Allergic Rhinitis \\
\hline \multicolumn{4}{|c|}{$(62.5 \%)$} \\
\hline
\end{tabular}

There were 21 patients with chronic sinusitis. Improvement in MEP was seen in 10 out of 34 ears among them.

\begin{tabular}{|c|c|c|}
\hline Patients with Chronic Sinusitis & Number of Ears & $\%$ \\
\hline $\begin{array}{l}\text { Decrease in Negativity of } \\
\text { MEP Post-Operatively }\end{array}$ & 10 & 29.4 \\
\hline $\begin{array}{l}\text { No Decrease in Negativity } \\
\text { of MEP Post-Operatively }\end{array}$ & 24 & 70.6 \\
\hline Total & 34 & 100 \\
\hline \multicolumn{3}{|c|}{$\begin{array}{l}\text { Table 6. Decrease in the Negativity of } \\
\text { MEP in Patients who had Chronic Sinusitis }\end{array}$} \\
\hline
\end{tabular}

\begin{tabular}{|c|c|c|c|}
\hline & $\begin{array}{c}\text { No. of Ears } \\
\text { with } \\
\text { Improvement } \\
\text { in MEP }\end{array}$ & $\begin{array}{c}\text { No. of Ears } \\
\text { with no } \\
\text { Improvement } \\
\text { in MEP }\end{array}$ & Total \\
\hline $\begin{array}{l}\text { Patients } \\
\text { with } \\
\text { Chronic } \\
\text { Sinusitis }\end{array}$ & $\begin{array}{c}10 \\
(29.4 \%)\end{array}$ & $\begin{array}{c}24 \\
(70.6 \%)\end{array}$ & $\begin{array}{c}34 \\
(100 \%)\end{array}$ \\
\hline $\begin{array}{l}\text { Patients } \\
\text { without } \\
\text { Chronic } \\
\text { Sinusitis }\end{array}$ & $\begin{array}{c}17 \\
(63 \%)\end{array}$ & $\begin{array}{c}10 \\
(37 \%)\end{array}$ & $\begin{array}{c}27 \\
(100 \%)\end{array}$ \\
\hline \multicolumn{4}{|c|}{$\begin{array}{l}\text { Table 7. Improvement in MEP in Patients } \\
\text { with \& without Chronic Sinusitis }\end{array}$} \\
\hline
\end{tabular}

\section{DISCUSSION}

Among 217 ears with intact tympanic membrane, 61 showed a negative MEP; and among these 61 ears, improvement in the MEP was seen postoperatively in 27 (44.3\%) cases. This shows that the degree of ETD was lessened in about half of the cases by undergoing septoplasty, and so DNS may be a factor that contributes to ETD.

Comparing these results with those of the earlier studies, in the study by Duran $\mathrm{K}$ et $\mathrm{al}^{1}$ the middle ear pressure improved by approximately $30 \%$ at the side of nasal obstruction and a statistically significant decrease was found at the side of nasal obstruction $(\mathrm{P}<0.05)$. In the study by Salvinelli $\mathrm{F}$ et al, 2 results of postoperative tubal function tests were significantly better than preoperative ones ( $90 \%$ versus $46 \%$; $P<0.001$ ). In the study by Abdel-Naby Awad OG et $\mathrm{al}^{3}{ }^{3}$ significant improvement in tympanometric values was found $(\mathrm{P}<0.05)$ postoperatively. Preoperatively, 93.3\% patients had sensation of ear fullness, but 30 days after surgery, only $66.7 \%$ had sensation of ear fullness, with significant improvement $(\mathrm{P}<0.001)$.

On the contrary, in the study by Sahin MI et al $^{8}$ middle ear pressures and Eustachian tube function did not differ significantly in the 1 st and $3 \mathrm{rd}$ postoperative months compared to the preoperative period ( $p>0.05)$. According to the study by Eyigör $\mathrm{H}$ et $\mathrm{al}^{9}$ on comparison of the preoperative and postoperative tympanometry results, no statistically significant difference was observed in middle ear pressures $(\mathrm{p}=0.375)$.

In the present study, improvement in MEP was seen only in $24.1 \%$ cases with allergic rhinitis, while improvement was there in $62.5 \%$ cases without it. The chi-square test showed a value of 9.075 with a p-value of 0.003 which had strong significance. The result is comparable to that of the study by Karatzanis AD et al ${ }^{14}$ which showed that improvement after septoplasty was less in patients who were also having allergic rhinitis.

In the present study, improvement in MEP was seen only in $29.4 \%$ cases with chronic sinusitis, while improvement was there in $63 \%$ cases without it. The chi-square test derived a value of 6.867 with a p-value of 0.009 which was also of high significance. The result is comparable to that of the study by Rudmik L et al 15 which showed that concurrent septoplasty does not appear to affect symptom outcomes in chronic sinusitis.

\section{CONCLUSION}

The study showed that about half of the cases showed improvement in MEP after septoplasty, and so DNS may be a factor that contributes to ETD. The study also shows that unless nasal allergy or chronic sinusitis are treated, there won't be much improvement in ETD by doing a septal correction alone in patients having any of these.

\section{REFERENCES}

[1] Duran K, Fatih Y, Doğan M. Middle ear pressure after septoplasty. J Craniofac Surg 2014;25(1):e19-21.

[2] Salvinelli F, Casale M, Greco F, et al. Nasal surgery and eustachian tube function: effects on middle ear ventilation. Clin Otolaryngol 2005;30(5):409-13.

[3] Abdel-Naby Awad OG, Salama YM, El-Badry M. Effect of nasal obstruction surgery on middle ear ventilation. The Egyptian Journal of Otolaryngology 2014; 30(3):191-5.

[4] Chmielik M, Gabryszewska A. The influence of diseases of the nose on the functioning of the eustachian tube and middle ear. Czytelnia Medyczna 2001:s 4-5.

[5] Mehrotra N, Arora M. The relationship between nasal septum deviation and middle ear pathology-a histo pathological study. Indian Journal of Otology 2005;11:21-3.

[6] Maier W, Krebs A. Is surgery of the inner nose indicated before tympanoplasty? Effects of nasal obstruction and reconstruction on the eustachian tube. Laryngorhinootologie 1998;77(12):682-8.

[7] Kamal NP, Harkare V. Nasal obstruction and eustachian tube dysfunction: how are they related? Int J Clin and Biomed Res 2015;1(3):46-50. 
[8] Şahin MI, Güleç S, Perişan U, et al. Does septoplasty affect middle ear pressure and eustachian tube function? Erciyes Med J 2014;36(3):115-8.

[9] Eyigör H, Osma U, Yllmaz MD, et al. The effect of operation success on middle ear ventilation in patients with nasal septal deviation. Kulak Burun Bogaz Ihtis Derg 2013;23(1):26-31.

[10] Davari R, Behnoud F. Study the effect of nasal obstruction surgery (Septoplasty) on eustachian tube function and middle ear pressure. J Ardabil Univ Med Sci 2014;14(4):322-30.

[11] Tan M, Kalcioglu MT, Akarcay M, et al. Does nasal septal deviation affect the success of tympanoplasty surgery? West Indian Med J 2015;64(4):393-6.
[12] Livi W, Mezzedimi C, Passàli GC, et al. Nasal obstruction and tubal functionality. Rivista Italiana di Otorinolaringologia Audiologia e Foniatria 2000;20(1):32-7.

[13] Filipović SA, Janosević L, Andrić V, et al. Clinical evaluation of eustachian tube transience and function in patients with different types of increased nasal resistance. Vojnosanit Pregl 2009;66(5):353-7.

[14] Karatzanis AD, Fragiadakis G, Moshandrea J, et al. Septoplasty outcome in patients with and without allergic rhinitis. Rhinology 2009;47(4):444-9.

[15] Rudmik L, Mace J, Ferguson BJ, et al. Concurrent septoplasty during endoscopic sinus surgery for chronic rhinosinusitis: does it confound outcomes assessment? Laryngoscope 2011;121(12):2679-83. 